\title{
The Role of So-Called English Medium Schools in Teaching of English in Karachi, Pakistan
}

\author{
Nadia Saeed ${ }^{1}$, Muhammad Ali Shaikh ${ }^{2}$, Stephen John ${ }^{2}$, Mahboob Dehraj ${ }^{3} \&$ Zahid Ali Sahito $^{4}$ \\ ${ }^{1}$ School of Foreign Languages, Central China Normal University, Wuhan, China \\ ${ }^{2}$ Sindh Madressatul Islam University, Karachi, Pakistan \\ ${ }^{3}$ Shaheed Benazir Bhutto University, Shaheed Benazirabad, Pakistan \\ ${ }^{4}$ Shah Abdul Latif University, Khairpur, Pakistan \\ Correspondence: Stephen John, Sindh Madressatul Islam University, Karachi, Pakistan. E-mail: \\ stephen_blessed@yahoo.com
}

\author{
Received: March 1, $2020 \quad$ Accepted: April 6, $2020 \quad$ Online Published: May 14, 2020 \\ doi:10.5539/ijel.v10n4p105 URL: https://doi.org/10.5539/ijel.v10n4p105
}

\begin{abstract}
The purpose of this research study was to investigate the role of so-called English Medium schools in the teaching of English. In Pakistan, English is considered a gateway to success, a person having command on the language is offered a job while the other one having command on the subject matter is rejected, therefore it is a common trend in Pakistan that people belonging to all walks of life prefer to send their children to privately managed English medium schools. To measure the role schools in teaching English, both quantitative and qualitative approaches were adopted, and by using a purposive random sampling procedure one hundred and twenty heads of so-called English medium schools were selected. A questionnaire having close-ended and open-ended items were used to getting the opinions of schools' heads regarding the role of school in teaching English. The quantitative responses were analyzed using SPSS while qualitative responses were sorted, labeled, and quantified. The data analysis reveals that privately managed schools are so-called English medium schools. They have neither qualified staff nor facilities which are required for the teaching of English.
\end{abstract}

Keywords: so-called English medium schools, teaching of English

\section{Introduction}

Pakistan is a part of those third world countries where $24.3 \%$ of the whole population is living below the poverty line and at the end of two years of the present government 18 million more people may slip into abject poverty due to low economic growth and double-digit food inflation (Tribune 3 March 2020). It is a part of the sub-continent that remains the part of the British colony for years and being the colonist the Britishers injected their religion, and culture in the colonized. Although people are poor, they not only love to wear western dress but also feel proud of speaking English. Even the poor people want their children to hold a top bureaucratic position which can be achieved by passing CSS (Civil Superior Services) examination and several good or creative brains having innovative ideas are unable to pass this exam because this exam is more or less is testing of English language skills and due to poor English language skills those creative/innovative ideas holders do not dare to participate and if participate are unable to pass, eventually, the top positions go into the basket of those who have a grip on this colonist language. Most people wish to learn the English language but also wish to see their children good in learning this language, they feel it's a gate to their success. In Pakistan, three types of schools i.e., government schools using Urdu (the national language) as a medium of instruction, private schools using English as a medium of instruction and Madrassas where religious education is more focused along with formal education. English medium schools can be further divided as elite schools established in posh and slump areas. The English medium schools working in slump areas can be named so-called English medium schools because such schools have neither essential facilities nor qualified staff to teach using the medium of English. But, keeping in view the importance of English, even poor people do not like to send their children to government or Urdu medium schools, they try to send their children to those schools where the English language is the medium of instruction.

Considering the wish of the parents' number of business-minded people have established such so-called English 
Medium Schools where teachers themselves have no grip on the language but they are teaching to the future of this nation using books published by Oxford or Cambridge presses. It is the ultimate reality that when teachers themselves have no command on a language then how can they teach it. Therefore, the English language skills of the students are becoming worsen. The number of such schools is increasing day by day as if someone is unable to get a job, he/she opens a school in his/her house and take the charge of spoiling the nation's future in his/her hands. The number of such so-called English medium schools is growing like mushrooms, where management not only violates the rules related to the building of a school but also compromises on the qualification of the teachers.

Parents or common people are very right in understanding the value of the English language because it enjoys a vital position as everything is written in English. The world has become a global village and English is the only source of communication whole information available on the internet is in English. Even those countries which were having hatred feeling for this language have started teaching English to their children and regret that why have they not started learning English years back. Education policies of Pakistan, especially the 2009 policy, have focused on the improvement of English language communication skills not only of the students but also of the teachers. In the curriculum, 2006 benchmarks are fixed for different levels. Minkova (2001) gives English the status of the Lingua Franca, as it has substituted French in international relations, Germany in scientific fields, and Latin in the area of literature. Presently English is the official language of forty-five countries of the world including Pakistan where Urdu is a declared official language but whole communication is done in English. Four basic skills are involved in learning any language of the world i.e., listening, speaking, reading, and writing. Languages are always learned by listening and speaking, just for understanding if we see a young child we find that no one teaches that child any rule related to a language but find that while speaking or using child follow or use those rule, if you ask a child a question-related to past, will answer in past but if ask related to future will answer in future. In Pakistan listening and speaking skills are ignored ultimately finding students weak in communication. Cole and Feng (2015) argue that it is the responsibility of a language teacher to arrange such activities in the classroom which motivates a learner to participate. In examination only writing skills are evaluated while others are skipped. According to Bridget (2009), the institutions where different societies are working and forcing students to use English for communication, the students are found good in English communication skills. It is very easy to improve the language skills of the students by taking feedback from parents whether the students follow the instruction at home or not Kasper and Petrello, (1998). Dzay and Medina (2002) supported the use of accurate listening resources for English as they improve listening skills. It is important to encourage students to express their ideas but it is most important to bring those ideas in written form Shaughnessy (1998). Both home (parents) and school (teachers) are bound and responsible to develop students' English language skills by sharing their experiences in writing, documentary activities, drafting as feedback, speaking, listening English programs on radio or TV to improve English language capabilities of students Beaven (1977). Vocabulary is the biggest problem for English learners; they need the help of their teachers and different resources like magazines, journals, and books so that their English vocabulary and writing abilities may be fruitfully improved Stahl (1985). Teachers may strengthen their students' writing competencies through different ways such as by assigning them creative type essays and assignments Vygotsky (1987). Teachers should take it as a priority to always motivate and engage students' English language activities in school, and parents are highly liable to check the home written assignments of their children for refining their writing skills Lee (2012). Kraemer (2008) emphasized that guideline indicates to a precisely arranged blend of both customary classroom direction and web-based learning exercises and declared it as an inventive curricular feature that considers patterns in remote dialect instruction. English language skills can be improved through the latest technology like using a computer by immediately correcting spelling and grammatical errors Ghandoura (2012), and Ismail (2009). Well-structured essays with enhanced ideas need advanced writing competency; spelling, handwriting, punctuations, rich vocabulary, and grammar are various sources that improve and refine English Language and command on all these sources to make a perfect writer. Writing competency may be highly developed and fully improved through brainstorming Troia and Graham (2002). The story, essay, and assignment writing, analyzing information, and summarizing are the different means and techniques to improve English language capabilities Persky, Daane and Jin (2003). Writing competency can be highly developed with the help of writing proper assignments as routine Bridgeman and Carlson (1984). Espinoza (2007), Langford (2007) and Mota (2007) considered English linguistic and socio-cultural contextual studies to gather data about those who attained higher linguistic competence in English. They had established more hours of instruction in elementary, secondary, and high school; the study relates consistency and continuity that make a difference in language instruction. Muralikrishna and Sunitha (2004) reported that human beings possess two ears and one tongue, it means that they have to listen more and speak less. Listening is a basic skill and it requires the process 
of receiving, interpreting, and responding. The ethics say that a listener needs to show agreement with the speaker's view. Tickoo (2009) further elaborates that listening requires attention in an organized manner.

\section{Objectives of the Research Study}

The general objective of this research study was to investigate the role of so-called English medium schools of Pakistan in the teaching of English while the specific objectives were to:

- Get first-hand knowledge about heads' academic/professional qualifications and availability of required resources to establish a school.

- Measure the level of understanding among the heads regarding the importance of the English language.

- Explore the resources available in their schools for teaching the English language.

- Identify the English language teachers' ability to use the available resources or implement the recommended approaches for the teaching of English.

\section{Research Questions}

Following research questions guided this research study:

- Are the heads employees or owners?

- Do the heads have a basic required professional qualification and administrative experience?

- What is the level of the school and how many rooms do they have?

- Do they have basic facilities needed for the teaching of English?

- Do they understand the importance of English in the present era of technology?

- Does school administration appoint qualified teachers for the teaching of English?

- Do the teachers use recommended language teaching techniques?

\section{Research Methodology}

Both quantitative and qualitative approaches were adopted to solve the query. A questionnaire consisting (14) close-ended and (02) open-ended questions was served to one hundred and twenty heads of the privately managed so-called English medium schools. But before final data collection, to check the reliability of the questionnaire it was piloted to the five (05) heads, which was measured (.68) using SPSS while for face and content validity, the questionnaire was shared with some senior researchers. Then keeping in view the suggestions of senior \& co-researchers and understanding of the respondents few items were amended or dropped. The population of this research study was the heads of so-called English medium schools established in areas where poor people reside, i.e., Shah Faisal, Landhi, and Korangi. One hundred and twenty heads of (forty from each town).

\section{Data Analysis, Findings and Discussion}

\subsection{Quantitative Data Analysis}

The collected demographic information and quantitative data were analyzed using SPSS, frequency, percent, valid percent, and cumulative percent of responses against each item were calculated.

\subsubsection{Level}

Most of the established schools in these areas are secondary level schools, which means having classes from Nursery to Matric.

\subsubsection{System}

Although this the general trend in Pakistan that parents do not like to send their children to such schools where boys and girls study together, but this research study has discovered that such so-called English medium schools which are established in three to four rooms building are having co-education system and parents are sending their children to those schools.

Table 1. School being administered by

\begin{tabular}{llllll}
\hline & & Frequency & Percent & Valid Percent & Cumulative Percent \\
\hline Valid & Male & 38 & 31.7 & 31.7 & 31.7 \\
& Female & 82 & 68.3 & 68.3 & 100.0 \\
& Total & 120 & 100.0 & 100.0 & \\
\hline
\end{tabular}


Most of the schools are administered by females as $68.3 \%$ heads were females while $31.7 \%$ were males who were looking after the day to day administrative matters of the schools.

Table 2. Status of employment

\begin{tabular}{llllll}
\hline & & Frequency & Percent & Valid Percent & Cumulative Percent \\
\hline Valid & Salaried Person & 36 & 30.0 & 30.0 & 30.0 \\
& Self-Employed & 84 & 70.0 & 70.0 & 100.0 \\
& Total & 120 & 100.0 & 100.0 & \\
\hline
\end{tabular}

Data reflect that $70 \%$ heads were the owners of the schools while only $30 \%$ heads were working as an employee, this reveals that educated people who have sense, establish their school and run it as a business.

Table 3. Academic qualification of the heads

\begin{tabular}{llllll}
\hline & & Frequency & Percent & Valid Percent & Cumulative Percent \\
\hline Valid & Intermediate & 4 & 3.3 & 3.3 & 3.3 \\
& BA/BSc & 35 & 29.2 & 29.2 & 32.5 \\
& MA/MSc & 76 & 63.3 & 63.3 & 95.8 \\
& M.Phil/MS & 4 & 3.3 & 3.3 & 99.2 \\
& PhD & 1 & .8 & .8 & 100.0 \\
Total & 120 & 100.0 & 100.0 & \\
\hline
\end{tabular}

$63 \%$ of heads were holding MA/MSC degrees, $29.2 \% \mathrm{BA} / \mathrm{BSc}$ while only one person was holding the highest academic qualification (Ph.D.).

Table 4. Professional qualification of the heads

\begin{tabular}{llllll}
\hline & & Frequency & Percent & Valid Percent & Cumulative Percent \\
\hline Valid & B.Ed & 61 & 50.8 & 50.8 & 50.8 \\
& M.Ed & 57 & 47.5 & 47.5 & 98.3 \\
& EPM & 2 & 1.7 & 1.7 & 100.0 \\
& Total & 120 & 100.0 & 100.0 & \\
\hline
\end{tabular}

Only two heads who were $1.7 \%$ of the whole sample were holding administrative degree EPM (Educational Planning and Management) which introduced by Allama Iqbal Open University (AIOU) Islamabad, while the other were having teaching profession related degrees.

Table 5. Teaching experience

\begin{tabular}{llllll}
\hline & & Frequency & Percent & Valid Percent & Cumulative Percent \\
\hline Valid & 1 to 5 Years & 18 & 15.0 & 15.0 & 15.0 \\
& 6 to10 Years & 81 & 67.5 & 67.5 & 82.5 \\
& 11 to 15 Years & 21 & 17.5 & 17.5 & 100.0 \\
& Total & 120 & 100.0 & 100.0 & \\
\hline
\end{tabular}

67.5 of \% heads were having 6 to 10 years of teaching experience which reflects that they could be well familiar with the pedagogies while only $15 \%$ were having 1 to 5 years' experience.

Table 6. Administrative experience

\begin{tabular}{llllll}
\hline & Frequency & Percent & Valid Percent & Cumulative Percent \\
\hline Valid & 1 to 5 Years & 62 & 51.7 & 51.7 & 51.7 \\
& 6 to10 Years & 46 & 38.3 & 38.3 & 90.0 \\
& 11 to 15 Years & 12 & 10.0 & 10.0 & 100.0 \\
& Total & 120 & 100.0 & 100.0 & \\
\hline
\end{tabular}


$51.7 \%$ of heads were having 1 to 5 years of administrative experience which reveals that they have joined this profession recently while only $10 \%$ of the heads were having 11 to 15 years of administrative experience, they could be considered well-experienced heads.

Table 7. No. of rooms

\begin{tabular}{llllll}
\hline & Frequency & Percent & Valid Percent & Cumulative Percent \\
\hline Valid & 4 to 6 & 81 & 67.5 & 67.5 & 67.5 \\
& 7 to 9 & 21 & 17.5 & 17.5 & 85.0 \\
& 10 and Above & 18 & 15.0 & 15.0 & 100.0 \\
& Total & 120 & 100.0 & 100.0 & \\
\hline
\end{tabular}

$67.5 \%$ of schools were having 4 to 6 rooms building. As schools included in the sample were secondary level schools, it means having 12 classes from Nursery to Matric (tenth level) therefore the rooms should be more than 10 but only $15 \%$ heads chose the option ' 10 and above' means others were having rooms lesser than the requirement and they could be fixing more than one class in a room violating the rule of the mental level of different age students in different classes.

Table 8. Library

\begin{tabular}{llllll}
\hline & & Frequency & Percent & Valid Percent & Cumulative Percent \\
\hline Valid & Yes & 3 & 2.5 & 2.5 & 2.5 \\
& No & 117 & 97.5 & 97.5 & 100.0 \\
& Total & 120 & 100.0 & 100.0 & \\
\hline
\end{tabular}

A library which is part and parcel of any education system was present only in 2.5 of $\%$ the schools, but quality and number of books available related to different subjects were again having a questions marks, it was the ultimate reality reflecting from the availability of rooms as rooms were not available for each class then how can someone expect that a room could have been reserved for a big library.

Table 9. Laboratories

\begin{tabular}{llllll}
\hline & & Frequency & Percent & Valid Percent & Cumulative Percent \\
\hline Valid & Both $2 \& 3$ & 21 & 17.5 & 17.5 & 17.5 \\
& None & 99 & 82.5 & 82.5 & 100.0 \\
& Total & 120 & 100.0 & 100.0 & \\
\hline
\end{tabular}

The heads were asked about the availability of a computer, computer lab with internet, science and language labs. 82.5 of \% heads selected the option 'None' while $17.5 \%$ declared that they have a computer lab with internet facility and science lab but none of the schools were having language lab to improve the language skills of the learners.

Table 10. The English language is a gateway to students' success

\begin{tabular}{llllll}
\hline & & Frequency & Percent & Valid Percent & Cumulative Percent \\
\hline Valid & Disagree & 6 & 5.0 & 5.0 & 5.0 \\
& Neutral & 39 & 32.5 & 32.5 & 37.5 \\
& Agree & 34 & 28.3 & 28.3 & 65.8 \\
& Strongly Agree & 41 & 34.2 & 34.2 & 100.0 \\
& Total & 120 & 100.0 & 100.0 & \\
\hline
\end{tabular}

The above table reveals that $34.2 \%$ and $28.3 \%$ respectively chose the options Strongly Agree \& Agree that learning of the English language will make learners successful in their lives while $32.5 \%$ respondents used the optional 'neutral' 
Table 11. English language skills are important for understanding the subject matter

\begin{tabular}{llllll}
\hline & & Frequency & Percent & Valid Percent & Cumulative Percent \\
\hline Valid & Neutral & 6 & 5.0 & 5.0 & 5.0 \\
& Agree & 60 & 50.0 & 50.0 & 55.0 \\
& Strongly Agree & 54 & 45.0 & 45.0 & 100.0 \\
& Total & 120 & 100.0 & 100.0 & \\
\hline
\end{tabular}

$50 \%$ and $45 \%$ of respondents respectively agreed and strongly agreed that without understanding English it will be difficult for learners to understand other subjects because other subjects are also in English.

Table 12. All skills i.e., listening, speaking, reading \& writing are must for learning the English language

\begin{tabular}{llllll}
\hline & & Frequency & Percent & Valid Percent & Cumulative Percent \\
\hline Valid & Neutral & 17 & 14.2 & 14.2 & 14.2 \\
& Agree & 49 & 40.8 & 40.8 & 55.0 \\
& Strongly Agree & 54 & 45.0 & 45.0 & 100.0 \\
& Total & 120 & 100.0 & 100.0 & \\
\hline
\end{tabular}

Although none of the schools were having a language lab for teaching language skills $40.8 \%$ and $45 \%$ of respondents used agreed and strongly agreed on options reflecting that they understand the importance of four basic skills for learning a language while $14.2 \%$ who chose the option 'Neutral' could be in fixed.

Table 13. The school has accurate listening resources to help students to improve their listening skills

\begin{tabular}{llllll}
\hline & Frequency & Percent & Valid Percent & Cumulative Percent \\
\hline Valid & Strongly Disagree & 9 & 7.5 & 7.5 & 7.5 \\
& Disagree & 13 & 10.8 & 10.8 & 18.3 \\
& Neutral & 88 & 73.3 & 73.3 & 91.7 \\
Agree & 10 & 8.3 & 8.3 & 100.0 \\
Total & 120 & 100.0 & 100.0 & \\
\hline
\end{tabular}

Only $8.3 \%$ of heads disclosed that they have listening resources in their school, while in the other schools these resources are missing, which can help teachers and students in improving their language skills.

Table 14. Audio-visual aids like radio, TV, etc. are used to improve students' language skills

\begin{tabular}{llllll}
\hline & & Frequency & Percent & Valid Percent & Cumulative Percent \\
\hline Valid & Strongly Disagree & 15 & 12.5 & 12.5 & 12.5 \\
& Disagree & 8 & 6.7 & 6.7 & 19.2 \\
& Neutral & 88 & 73.3 & 73.3 & 92.5 \\
& Agree & 9 & 7.5 & 7.5 & 100.0 \\
& Total & 120 & 100.0 & 100.0 & \\
\hline
\end{tabular}

Only $09 \%$ of respondents used the option to agree that they use audio-visual aids to improve the language skills of the students. This analysis reveals that such facilities may not be available in $91 \%$ of schools.

Table 15. Magazines, journals, and books are available as resources to teach vocabulary to students

\begin{tabular}{llllll}
\hline & & Frequency & Percent & Valid Percent & Cumulative Percent \\
\hline Valid & Disagree & 4 & 3.3 & 3.3 & 3.3 \\
& Neutral & 19 & 15.8 & 15.8 & 19.2 \\
& Agree & 50 & 41.7 & 41.7 & 60.8 \\
& Strongly Agree & 47 & 39.2 & 39.2 & 100.0 \\
& Total & 120 & 100.0 & 100.0 & \\
\hline
\end{tabular}


$41.7 \%$ and $39.2 \%$ of respondents respective agreed and strongly agreed that reading material i.e. magazines journals and books are available but if we compare these responses with the responses of heads when they were asked about the presence of the library (only in $2.5 \%$ schools library was present, Item-6.10).

Table 16. The latest technology is provided to help students to improve their English language skills

\begin{tabular}{llllll}
\hline & Frequency & Percent & Valid Percent & Cumulative Percent \\
\hline Valid & Strongly Disagree & 8 & 6.7 & 6.7 & 6.7 \\
& Disagree & 41 & 34.2 & 34.2 & 40.8 \\
& Neutral & 17 & 14.2 & 14.2 & 55.0 \\
Agree & 27 & 22.5 & 22.5 & 77.5 \\
& Strongly Agree & 27 & 22.5 & 22.5 & 100.0 \\
Total & 120 & 100.0 & 100.0 & \\
\hline
\end{tabular}

$22.5 \%$ of heads used both options (Strongly Agree \& Agree) declaring that they have the technology for teaching language which again has contradiction with their response about the availability of computer lab in the school (Item-5.11).

Table 17. Societies are established in the school which force/encourage students for the use of English in communication

\begin{tabular}{llllll}
\hline & Frequency & Percent & Valid Percent & Cumulative Percent \\
\hline Valid & Strongly Disagree & 8 & 6.7 & 6.7 & 6.7 \\
& Disagree & 41 & 34.2 & 34.2 & 40.8 \\
& Neutral & 17 & 14.2 & 14.2 & 55.0 \\
& Agree & 31.7 & 31.7 & 86.7 \\
& Strongly Agree & 16 & 13.3 & 13.3 & 100.0 \\
& Total & 120 & 100.0 & 100.0 & \\
\hline
\end{tabular}

Societies could be existing only in $45 \%$ schools as heads chose (31.7\% agree and $13.3 \%$ Strongly agreed). Such bodies are also strongly recommended by several researchers for assisting teachers in teaching language skills.

Table 18. Language teachers know the proper use of listening resources

\begin{tabular}{llllll}
\hline & Frequency & Percent & Valid Percent & Cumulative Percent \\
\hline Valid & Strongly Disagree & 9 & 7.5 & 7.5 & 7.5 \\
& Disagree & 52 & 43.3 & 43.3 & 50.8 \\
& Neutral & 39 & 32.5 & 32.5 & 83.3 \\
Agree & 20 & 16.7 & 16.7 & 100.0 \\
& Total & 120 & 100.0 & 100.0 & \\
\hline
\end{tabular}

Only $16.7 \%$ of respondents agreed that they know how to use listening resources, while others selected Neutral, Disagree, or Strongly Disagree.

Table 19. Language teachers motivate students to express their ideas verbally only

\begin{tabular}{llllll}
\hline & & Frequency & Percent & Valid Percent & Cumulative Percent \\
\hline Valid & Disagree & 44 & 36.7 & 36.7 & 36.7 \\
& Neutral & 56 & 46.7 & 46.7 & 83.3 \\
& Agree & 20 & 16.7 & 16.7 & 100.0 \\
& Total & 120 & 100.0 & 100.0 & \\
\hline
\end{tabular}

Only $16.7 \%$ of heads chose the option agreed that their teachers motivate their students to express their ideas verbally in English and according to researchers and scholars a language is learned by listening and speaking. As most of the teachers, themselves do not communicate English therefore their students also remain hesitant throughout life in expressing their ideas in English. 
Table 20. Language teachers arrange such activities in the classroom which motivates learners to participate

\begin{tabular}{llllll}
\hline & & Frequency & Percent & Valid Percent & Cumulative Percent \\
\hline Valid & Disagree & 44 & 36.7 & 36.7 & 36.7 \\
& Neutral & 56 & 46.7 & 46.7 & 83.3 \\
& Agree & 20 & 16.7 & 16.7 & 100.0 \\
& Total & 120 & 100.0 & 100.0 & \\
\hline
\end{tabular}

Classroom activities are recommended by researchers and scholars because activities actively engage the learners in learning but only $16.7 \%$ of respondents agreed that their English language teachers are using activities in the classroom.

Table 21. Teachers themselves must have good English language communication skills

\begin{tabular}{llllll}
\hline & & Frequency & Percent & Valid Percent & Cumulative Percent \\
\hline Valid & Disagree & 4 & 3.3 & 3.3 & 3.3 \\
& Neutral & 29 & 24.2 & 24.2 & 27.5 \\
& Agree & 38 & 31.7 & 31.7 & 59.2 \\
& Strongly Agree & 49 & 40.8 & 40.8 & 100.0 \\
& Total & 120 & 100.0 & 100.0 & \\
\hline
\end{tabular}

Most of the heads agreed that the language teachers themselves have command on the language they teach.

Table 22. School engages students in writing stories and essays

\begin{tabular}{llllll}
\hline & & Frequency & Percent & Valid Percent & Cumulative Percent \\
\hline Valid & Disagree & 4 & 3.3 & 3.3 & 3.3 \\
& Neutral & 29 & 24.2 & 24.2 & 27.5 \\
& Agree & 45 & 37.5 & 37.5 & 65.0 \\
& Strongly Agree & 42 & 35.0 & 35.0 & 100.0 \\
& Total & 120 & 100.0 & 100.0 & \\
\hline
\end{tabular}

The heads chose $37.5 \%$ and $35 \%$ respectively agree and strongly agreed for arranging writing skills related activities and these are normally arranged by most of the schools in Pakistan.

Table 23. Parents' feedback is very important to improve language skills

\begin{tabular}{llllll}
\hline & Frequency & Percent & Valid Percent & Cumulative Percent \\
\hline Valid & Strongly Disagree & 9 & 7.5 & 7.5 & 7.5 \\
& Disagree & 13 & 10.8 & 10.8 & 18.3 \\
& Neutral & 30 & 25.0 & 25.0 & 43.3 \\
& Agree & 25.0 & 25.0 & 68.3 \\
& Strongly Agree & 30 & 31.7 & 31.7 & 100.0 \\
& Total & 120 & 100.0 & 100.0 & \\
\hline
\end{tabular}

The researchers have proved that nothing is possible till a learner does not practice at home, therefore teachers need parents' cooperation through feedback but in the present sample only $31.1 \%$ and $25 \%$ of respondents respectively chose Strongly Agree and Agree for the importance of feedback in learning a language.

\subsection{Qualitative Data Analysis}

\subsubsection{What Are the Major Issues You Face Related to the Availability of Resources?}

The responses against this open-ended question were sorted, labeled, and quantified and it is found that almost all respondents were blaming that the government is not cooperating with them.

\subsubsection{Any Suggestion for Improvement of the Education System for the Betterment Future}

Again, the respondents were looking for financial support of the government. 


\section{Conclusions}

$70 \%$ heads are self-employed, do have basic academic \& professional qualification and teaching \& administrative experience but neither have required the number of rooms $(67.5 \%$ having 4 to 6 rooms building but running secondary level schools) nor have facilities (No library $=97.5 \%$, and No laboratory $=82.5 \%$ ). The heads and teachers understand the importance of English in the present era of technology but they do not follow the recommended rules for teaching English moreover they blamed that the government is non-cooperative, therefore we cannot expect that such schools can contribute to the teaching of English language skills.

\section{Recommendations}

The government should intervene/support such schools because without government sincere efforts nothing is possible and ultimately parents' dream of sending their children to schools for learning English will not come true.

\section{References}

Abdulwahed, A. I. S. (2011). Exploring Students' Perceptions of ESL Writing. English Language Teaching, 4(2), 73. https://doi.org/10.5539/elt.v4n2p73

Agrawal, L. (1995). General Language Practices. New York, USA: Merrill Publishing Company.

Avinashilingam, N. A. V., \& Sharma, G. (2005). Identification of Factors Influencing the Students' Academic Performance. Journal of Educational Research and Extension, 42(1), 25-32.

Beaven, M. (1977). Individualized goal setting, self-evaluation, and peer evaluation. In C. R. Cooper \& L. Odell (Eds.), Evaluating Writing (pp. 135-156). Urbana, IL: National Council of Teachers of English.

Bridgeman, B., \& Carlson, S. B. (1984). Survey of academic writing tasks. Written Communication, 1, 247-280. https://doi.org/10.1177/0741088384001002004

Bridget, O. (2009). Education. Chula Vista. Summer, 129(4), 571-573. Retrieved from http://proquest.umi.com

Cole, J., \& Feng, J. (2015, April). Effective Strategies for Improving Writing Skills of Elementary English Language Learners. Paper presented at the Chinese American Educational Research and Development Association Annual Conference, Chicago. Retrieved from https://files.eric.ed.gov/fulltext/ED556123.pdf

Dwivedi, Y. K., Khoumbati, K., Williams, M. D., \& Lal, B. (2007). Factors affecting consumers' behavioral intention to adopt broadband in Pakistan. Transforming Government: People, Process and Policy, 1(3), 285-297. https://doi.org/10.1108/17506160710778112

Dzay, F., \& Medina, S. (2002). Auténtico de audio en la enseñanzade lidiomainglés. Unpublished master's dissertation. Instituto de estudios universitarios, Quintana Roo, México.

Elke, S., \& Tsila, E. (2009). Linguistic intervention techniques for At-Risk English language learners. Foreign Language Annals, 42(1), 55-76. https://doi.org/10.1111/j.1944-9720.2009.01008.x

Espinoza, L. (2007). Instrucción Escolar y suRelación con el Nivel de Competencia Lingüística en Inglés en Estudiantes de Nuevo Ingreso a lasInstituciones de Educación Superior en Aguascalientes. Unpublished master's dissertation. Universidad Autónoma de Aguascalientes.

Ghandoura, W. A. (2012). A qualitative study of ESL college students' attitudes about computer-assisted writing classes. English Language Teaching, 5(4), 57-64. https://doi.org/10.5539/elt.v5n4p57

HEC. (2009). Higher Education Commission. Govt. of Pakistan, Islamabad.

Kasper, L. F., \& Petrello, B. A. (1998). Responding to ESL Student Writing: The Value of a Non-judgmental Approach. Community Review, 161-178.

Kraemer, A. (2008). Engaging the foreign language learner: using hybrid instruction to bridge the language-literature gap. Ph.D. Dissertation. Michigan State University, East Lansing, MI.

Langford, P. (2007). Competencia lingüistica en inglés y razonamiento verbal y español. Un estudio con estudiantes de nuevo ingreso a instituciones de educación superior en Aguascalientes en 2006. Unpublished master's dissertation. Universidad Autónoma de Aguascalientes, México.

Lee, H. (2012). The reading response e-journal: An alternative way to engage low-achieving EFL students. Language Teaching Research, 17(1), 111-131. https://doi.org/10.1177/1362168812457539

Meera, K. P., \& Remya, P. (2010). Effect of extensive reading and creativity on achievement in the English language. E-Journal of All India Association for Educational Research, 22(1), 16-22. 
Ministry of Education. (2009). National Education Policy. Govt. of Pakistan, Islamabad.

Minkova, D., \& Stockwell, R. (2001). English words: History and structure: A Case Study. Asian Social Science, 8(3), 88-99. https://doi.org/10.1017/CBO9780511791161

Muralikrishna, C., \& Sunitha, M. (2004). Communication Skills for Engineers. Pearson.

Persky, H. R., Daane, M. C., \& Jin, Y. (2003). The nation's report card: Writing 2002 (NCES 2003-529). Washington, D. C: National Centre for Education Statistics, Institute of Education Sciences, U.S Department of Education. https://doi.org/10.1037/e492152006-007

Shaughnessy, M. P. (1988). Diving in: An introduction to basic writing. In G. Tate, E. P. J. Corbett \& N. Myers (Eds.), The Writing Teacher's Sourcebook (pp. 321-326). New York: Oxford University Press.

Stahl, S. (1985). To teach a word well: A framework for vocabulary instruction. Reading World, 24(913), 16-27. https://doi.org/10.1080/19388078509557828

Thomas, J. B., Clark, S. M., \& Gioia, D. A. (1993). Strategic sensemaking and organizational performance: Linkages among scanning, interpretation, action, and outcomes. Academy of Management Journal, 36(2), 239-270. https://doi.org/10.2307/256522

Tickoo, M. L. (2009). Teaching and Learning English: A Sourcebook for Teachers and Teacher-Trainers. India: Orient Blackswan Pvt Ltd.

Troia, G., \& Graham, S. (2002). The effectiveness of a highly explicit, teacher-directed strategy instruction routine: Changing the writing performance of students with learning disabilities. Journal of Learning Disabilities, 35, 290-305. https://doi.org/10.1177/00222194020350040101

Vazalwar, C., \& Yadav, R. (2005). Tracing out the Relationship of Reading Comprehension in English concerning Anxiety, Socio-Economic Status, and School Environment. Ram-Eesh Journal of Education, 2(1), 27-31.

Vygotsky, L. S. (1987). The Collected Works of L. S. Vygotsky: Problems of General Psychology. New York, US: Springer. https://doi.org/10.1007/978-1-4613-1655-8

Yount, W. (2006). Research Design and Statistical Analysis for Christian Ministry. Fort Worth, Tex.: W.R. Yount.

\section{Copyrights}

Copyright for this article is retained by the author, with first publication rights granted to the journal.

This is an open-access article distributed under the terms and conditions of the Creative Commons Attribution license (http://creativecommons.org/licenses/by/4.0/). 